\title{
Recovery of State Benefits from Tort Damages: Legislating For or Against the Welfare State?
}

\author{
Richard Lewis \\ Professor, Cardiff Law School
}

This chapter deals with statutes which have established a system for recovering from damages in tort certain state benefits obtained by those who have suffered personal injury. These state benefits may take the form of social security monies or health care services. A small part of the vast public expenditure upon health and welfare can thus be returned to the Exchequer. The statutes involved are, firstly, the Social Security (Recovery of Benefits) Act 1997 ('the 1997 Act') which replaced the relevant sections of the Social Security Act 1989 Act ('the 1989 Act') and secondly, the Road Traffic (NHS Charges) Act 1999 ('the 1999 Act') as extended by Part III of the Health and Social Care (Community Health and Standards) Act 2003. ${ }^{1}$

These statutes are placed here in their wider policy context and, in particular, the political climate which led to their enactment is considered. The often uneasy relationship between tort law and the welfare state is discussed. The question posed in the title to this chapter in effect asks whether the reforms merely made provision for the two systems of compensation to operate more effectively together, or whether they enabled tort to become entrenched at the expense of a welfarist approach which would have laid more emphasis upon community responsibility for injury rather than the wrongdoing of individuals.

\footnotetext{
${ }^{1}$ The 1989 Act establishing the social security recovery scheme came into effect in the following year. The 1999 Act which founded the recovery of NHS costs was extended by the 2003 Act beyond road traffic cases to all successful personal injury claims. However, the extension did not come into effect until January 2007. Relatively minor changes were also made by the Social Security Act 1998 which affected the grounds for appeal, and the Child Maintenance and Other Payments Act 2008.
} 


\section{THE IMPORTANCE OF THE LEGISLATION}

If we were to assess the importance of legislation by the amount of academic interest and writing upon the subject we would conclude the benefit recovery scheme was an insignificant development in tort. Apart from a book ${ }^{2}$ and various articles by the present author, ${ }^{3}$ there are almost no academic publications upon the subject, ${ }^{4}$ and it is given little space in tort textbooks. This is consistent with the general approach of academics towards the law of tort: the theme of this book is that statutes do not receive the attention they deserve. ${ }^{5}$ But a wider point can be made here about the partiality of tort scholarship: it concentrates excessively upon issues of liability as opposed to damages. This bias is a remarkable one as far as practitioners are concerned. They are bemused by the pre-occupation of academics with the rules on fault and cause. This is because they are aware that, in practice, defendants and their insurers rarely challenge liability. The issue is raised in less than twenty per cent of personal injury cases. ${ }^{6}$ By contrast, the amount of compensation is almost always

\footnotetext{
${ }^{2}$ R. Lewis, Deducting Benefits from Damages for Personal Injury (Oxford: OUP, 1999).
}

${ }^{3}$ R. Lewis, "Deducting Collateral Benefits from Damages: Principle and Policy" (1998) 18 Legal Studies 15, "The Overlap between Damages for Personal Injury and Work Related Benefits" (1998) 27 Industrial LJ 1, "Recovery of NHS Accident Costs: Tort as a Vehicle for Raising Public Funds" (1999) 62 MLR 903, “Deducting Which Benefits from What Heads of Damage?” [1999] J Personal Injury Law 11, and "The Impact of Social Security Law on the Recovery in Tort of Damages for Personal Injury" in U. Magnus (ed), The Impact of Social Security on Tort Law (Vienna and New York: Springer Publishers, 2003) 56 - 85.

${ }^{4}$ But see N. Wikeley, annotations to the 1989 Social Security Act in Current Law Statutes, and A. Dismore, "Social Security (Recovery of Benefits) Act 1997 and Regulations" [1998] J Personal Injury Law 14.

${ }^{5}$ See especially J. Dietrich, "Teaching Torts in the Age of Statutes and Globalisation" (2010) 18 Torts LJ 141.

${ }^{6}$ T. Goriely, R. Moorhead and P. Abrams, More Civil Justice? The Impact of the Woolf Reforms on Pre-Action Behaviour (London: The Law Society and the Civil Justice Council, 2002) 103. However, liability was more readily denied in another survey conducted by the Association of Personal Injury 
open to some negotiation. Tort in practice provides a structure for processing mass payments of small amounts of compensation; only very rarely does it stage a gladiatorial contest to determine whether a particular defendant was in the wrong. Therefore, in considering legislation which primarily deals with damages issues, this chapter goes a little way towards redressing another bias in tort scholarship.

In contrast to academics, practitioners immediately recognised the importance of the benefit recovery scheme. Before it was introduced professional development courses on the subject were numerous and well attended. Practitioners appreciated that all of their personal injury cases would be affected no matter whether determined in court or, much more commonly, settled out of it. ${ }^{7}$ Each of the 987,381 claims presently being brought a year ${ }^{8}$ has to be officially notified, and later, when damages are being considered, both claimants and defendants must take account of the benefits which may be recovered to assess the true amount of any settlement offer.

A new Government agency, the Compensation Recovery Unit (CRU) has been set up to administer the recovery scheme. Those acting on behalf of defendants, usually insurers, not only have the duty to notify CRU of each claim but also, before they pay any damages, they must ask CRU what is the value of the benefits that the claimant

Lawyers, Potential Impact of the Threshold Limit for Personal Injury Cases within the Small Claims Court being raised to $£ 5000$ (APIL, 2005).

${ }^{7}$ Before being set down for trial 98 per cent of cases are settled and many more are concluded before any hearing takes place. The Report of the Royal Commission on Civil Liability and Compensation for Personal Injury (1978, cmnd 7054), chairman Lord Pearson (the Pearson report) vol 2 table 12. Similarly P. Pleasence, Personal Injury Litigation in Practice (London: Legal Aid Board Research Unit, 1998) at 12 reveals that only 5 out of the 762 "ordinary" cases with costs of less than $£ 5,000$ went to trial.

\footnotetext{
${ }^{8}$ Department of Work and Pensions, Compensation Recovery Unit Statistics 2010-11 http://www.dwp.gov.uk/other-specialists/compensation-recovery-unit/performance-andstatistics/performance-statistics. The number of claims has risen significantly in recent years. After remaining relatively stable for the five years before 2004 - 05 when they numbered 755,875, they have steadily risen in the six years since by 30 per cent. Motor claims largely account for this. During the last six years they increased by 64 per cent from 402,892 to 659,671 .
} 
has received as a result of the accident or disease. CRU then investigates the relevant social security payments and health service treatments and certifies the amount of money involved. On paying the damages, the compensator must repay this amount to CRU. This reimbursement has become part of the administrative process involved in disposing of every personal injury claim. Practitioners now regard the procedure as routine. The statistics gathered by CRU about the personal injury system provide a key source of information about the operation of the law of tort.

The legislation is also important because of its effect upon the tactics used in the bargaining process preceding the settlement of claims. The recovery from damages of the benefits received during the negotiation process leads to a mounting bill which eventually must be repaid to the state. Usually the longer the claimant is on benefit awaiting settlement of his tort claim, the more is deducted from the damages which are eventually obtained. The pressure to keep the recovery bill as low as possible can act as a powerful incentive to achieve a settlement as quickly as possible. It is the claimant who is the more likely to be subject to this time pressure, although it can affect both parties. "Settle today and keep tomorrow's benefits; settle tomorrow and lose them" is often a persuasive argument. It helps to ensure that the litigation is conducted efficiently, although there is concern that the pressure may not always be conducive to fair settlements. ${ }^{9}$

The importance of the scheme to the public purse is revealed by the fact that in 2010 - 11 about $£ 140$ million in social security benefits ${ }^{10}$ and $£ 195$ million in health treatment costs ${ }^{11}$ were recovered. The state in effect is often a defendant in tort cases

\footnotetext{
${ }^{9}$ For a general discussion of tactical use of the legislation in settlement negotiations see Lewis op cit above note 2 para 13.19 et seq and 15.02 et seq.

${ }^{10}$ Department of Work and Pensions, Compensation Recovery Unit Statistics 2010-11 http://www.dwp.gov.uk/other-specialists/compensation-recovery-unit/performance-and$\underline{\text { statistics/performance-statistics }}$

${ }^{11}$ Department of Health, NHS Injury Costs Recovery Scheme, Amounts Collected 2010-11 http://www.dh.gov.uk/prod_consum_dh/groups/dh_digitalassets/documents/digitalasset/dh_125921.pdf
} 
because of claims brought against public bodies, notably the National Health Service ${ }^{12}$ and the Ministry of Defence. ${ }^{13}$ It pays large amounts of damages. Now it has an additional and different interest in the operation of the system of compensation for personal injury: it can make money out of it. Public funds can be replenished. As discussed below, study of the recovery of benefits legislation reveals the wider political influences that shaped it, and this includes pressures to make savings in public expenditure. Although the politics of statutory reform is more likely to attract the attention of academics than changes made in the common law, studies of political influences upon any reforms made in the law of tort remain few and far between. This chapter in part provides one example.

\section{Tort and the welfare state}

Finally, this legislation is important because it explores the relationship between tort and the welfare state. Although only a small part of public expenditure upon welfare is paid to accident victims, ${ }^{14}$ the amount greatly exceeds the total damages paid by the tort system. In reality tort is very much the "junior partner" of the social security system. ${ }^{15}$ The Pearson Commission in 1978 found that seven times as many accident victims received social security payments as opposed to tort damages for

${ }^{12}$ In 2010-11 there were 13,022 claims for clinical negligence representing $1.3 \%$ of the total notified to the CRU. See note 11 above.

${ }^{13}$ In 2008-09 there were 4,732 claims brought which would be $0.57 \%$ of all the claims notified to the CRU that year. However, that percentage is actually lower than this because a number of MOD claims relate to other than personal injury and therefore do not need to be notified. See the Ministry of Defence, Claims Annual Report http://www.mod.uk/NR/rdonlyres/4995F4DD-229A-4F91-8D416B1EFCD72B50/0/claims_annual_report_0809.pdf

${ }^{14}$ The Pearson Commission op cit above note 7 at vol 1 para 87 roughly estimated that in 1978 only about 6 per cent of public expenditure upon welfare was directed towards accident victims. This represented about 2 per cent of total public expenditure at that time (welfare provision then being a third of the total). The calculation took into account the cash benefits and costs of administration of the social security system and added to it the costs of hospital and medical services.

${ }^{15}$ Pearson Commission op cit note 7 at vol 1 para 1732. 
their injuries, and the total benefit obtained by them was double the sum of all damages awarded. ${ }^{16}$ Tort becomes even less significant if its importance is assessed not in relation to accident victims alone, but in relation to the ten times larger group of people who are disabled from all causes, these predominantly being illness and disease. For a variety of reasons this group is much less able to claim in tort than accident victims, ${ }^{17}$ and common law damages plays an even more limited role in their compensation.

These figures must not be taken to imply that the tort and social security systems are mutually exclusive; in fact they are closely linked. The person who succeeds in his damages claim is more likely to be in receipt of a wider range of welfare benefits than the more typical accident victim who is unable to claim in tort. In a Law Commission survey nine out of ten recipients of damages of $£ 20,000$ or more also received, on average, three different social security benefits. ${ }^{18}$ The existence of the welfare state has provided injured people with the basic sustenance needed to undergo the sometimes lengthy process of pursuing a claim for damages at common law. If accident victims had not been able to obtain this immediate support from the benefit system it is unlikely that the action for common law damages - with all its delays, costs and complexity - would have survived long into the twentieth century. For that reason the tort system can be seen as parasitic upon the welfare state. It is similarly dependent upon liability insurance. ${ }^{19}$

\footnotetext{
${ }^{16}$ The Pearson Commission op cit above note 7 at vol 1 table 4 suggested that in 1977 there were about 215,000 recipients of damages totalling $£ 200$ million whereas the social security system paid out about $£ 420$ million to one and a half million people. By 1988 although more people were receiving tort damages, the relative importance of the schemes remained about the same. The Lord Chancellor's Department, Report of the Review Body on Civil Justice (1988, cm 394) para 391.

${ }^{17}$ J. Stapleton, Disease and the Compensation Debate (Oxford: OUP, 1986).

${ }^{18}$ Law Commission Report No 225 (1994) Personal Injury Compensation: How Much Is Enough?
} Table 901.

${ }^{19}$ Jenny Steel, Risks and Legal Theory (Oxford: Hart Publishing, 2004) 36: “Insurance 'technology’ underlies the whole practice of tort law." Without insurance, it is probable that tort liability itself could 
In two senses, therefore, compensation from tort can be seen as secondary to welfare benefit: firstly, tort is a less important source of compensation for accident victims than social security; and secondly, its compensation is paid only after benefits have been received. The last point is of fundamental importance to this chapter for, if benefits are already in payment, there is then the possibility that later compensation will duplicate the provision already made. This now leads us to consider the problems posed by the overlapping systems of compensation.

\section{THE RECOVERY SCHEME AND “COLLATERAL BENEFITS” ISSUES IN WIDER CONTEXT}

To place the recovery of benefits statutes in their wider context it must be appreciated that welfare payments and medical assistance are not the only "collateral" benefits which may be provided to a claimant following injury. A variety of sources may be involved. Apart from the state, the main providers of financial support are employers and insurers, although some charitable money and help from friends and family may also be involved. Employers, for example, may continue to pay wages following injury. In the longer term they may fund a disability pension which may be administered by an insurance company. Insurers may also be directly involved when paying monies under sickness, accident or life policies prudently bought by the claimant himself. They also may provide private medical care in some cases.

In assessing damages in tort, therefore, it has to be considered to what extent these other sources of compensation and support are to be taken into account to reduce the monies to be paid, and also whether these additional providers may claim reimbursement. The basic policy questions that arise are set out below. How the legal rules have changed over time in an attempt to resolve these questions enables us to understand the wider historical context to the benefit recovery scheme.

not survive. See J. G. Fleming, The American Tort Process (Oxford: Clarendon Press, 1988) 21, R. Lewis, "Insurance and the Tort System" (2005) 25 (1) Legal Studies 85, R. Lewis, "How Important Are Insurers In Compensating Claims for Personal Injury In The UK?” (2006) 31 (2) The Geneva Papers on Risk and Insurance 323. 


\section{The basic policy questions}

The problems posed by collateral benefits give rise to two general questions. The first is "to what extent are damages for personal injury reduced to take account of the receipt of benefits from other sources?" The second is "are the providers of these benefits to obtain reimbursement from the person who caused the wrongful injury?" Broadly there are three solutions to these questions: ${ }^{20}$

\section{(1) Cumulation}

Here the damages take no account of the other sources of compensation. The claimant receives damages in full irrespective of the extent to which his losses may have been made good by other sources. For claimants, this is the most favourable of the three solutions because it enables them to receive compensation from several sources without being required to repay the providers of their collateral benefits. The result is sometimes called an application of 'the collateral source rule,' which is defined by the USA Restatement of Torts as follows:

"Payments made to or benefits conferred on the injured party from other sources are not credited against the tortfeasor's liability, although they cover all or a part of the harm for which the tortfeasor is liable." 21

Although the rule ensures that undue credit is not given to the defendant, it also appears to over-compensate the injured person by ignoring the receipt of additional money. On the surface, therefore, the solution appears wasteful. However, arguments can be made to support the rule in particular cases. For example, if the payment of damages is seen as inadequate to meet the claimant's needs or if it is for a purpose different from that of the collateral benefit there should be no deduction. A similar result may be thought appropriate if the claimant himself has paid for the collateral

\footnotetext{
${ }^{20}$ The classic analysis is by John Fleming, "The Collateral Source Rule and Loss Allocation in Tort" (1966) 54 Cal L Rev 1478, and “Collateral Benefits” in International Encyclopaedia of Comparative Law (Vol. XI) chap 11. Fleming’s views are reassessed by Harold Luntz, "The Collateral Source Rule Thirty Years On" in P. Cane and J. Stapleton, The Law of Obligations: Essays in Celebration of John Fleming (Oxford: Clarendon Press, 1998). See further Lewis, op cit above note 2 chapters 2 - 5.

${ }^{21} 2^{\text {nd }}$ Restatement of Torts (1977) s 920 A (2).
} 
benefits received: his prudence and foresight should then be rewarded by allowing him to retain the additional compensation.

\section{(2) Reduction}

Here the damages are reduced by the amount of the benefit received, but the provider of the collateral source is given no right to seek reimbursement. Claimants receive less money, and the danger of overcompensation and waste is avoided. Reduction produces the most favourable result for defendants because not only do they pay lower damages to claimants, but they also have no duty to refund the payments made by the collateral providers. However, this solution has been seen as the least attractive of the three because the wrongdoer seems to be subsidised at the expense of the Good Samaritan provider and this offends our sense of morality. Reduction also undermines the supposedly deterrent functions of the law of tort. It limits the financial penalty imposed for careless behaviour and thus, in theory, lessens the incentive to minimise the risk of causing injury. The objection is that it reduces the extent to which the tortfeasor bears responsibility for his actions. However, the policy of reduction can be defended on the basis of its simplicity and because it avoids the administrative cost which recoupment can entail.

\section{(3) Recoupment}

By contrast, this solution arranges not only for the benefit to be taken into account when assessing damages but also for the provider of the collateral benefit to be reimbursed. This not only prevents the injured person from being overcompensated but also ensures that the wrongdoer does not benefit from the payments made by the collateral source. Although the collateral payments may help to meet the claimant's immediate needs, ultimately they must be refunded by the tortfeasor. On the surface, provided the administrative cost of arranging repayment of the benefit is not too high, this appears the most attractive of the three solutions.

The policy is especially attractive to those who recognise that the tort system is extravagant and wasteful in many respects. In theory money provided by the state could be saved and reallocated to those who are seriously disabled but unable to mount a tort claim. As stated above, we know that damages are obtained by only a 
small minority of accident victims who, in turn, constitute but a fraction of those disabled from all causes. If state support could be transferred from the "elite group" 22 to those less fortunate there would be a more equitable redistribution of the finite resources available. The difficulty with this lies in the presumptions that recipients of tort damages are indeed overcompensated, and furthermore that any savings made could be reallocated easily and equitably to compensate others. In practice, if a collateral source is refunded, the monies are rarely earmarked for reallocation for a similar purpose. Instead the savings are absorbed into the general pool. This happens, for example, where the state reduces expenditure by "targeting" benefits for disabled people more precisely. The savings made are not used to improve allied provision but disappear instead into the general coffers of the Treasury. In short, although in theory recoupment appears to offer the possibility of a more egalitarian redistribution of resources, in practice it rarely occurs.

\section{THE MOVE AWAY FROM CUMULATION OF BENEFIT}

Which of the above solutions does the law adopt? The answer is that to a greater or lesser extent it adopts all three. The variety in approach is partly explained by the different kinds of collateral payment: they may be funded from distinct sources, some private, some public; and they may aim to compensate for very different losses. We would not necessarily expect the same rule to be applied to all situations. ${ }^{23}$ However, from a broad historical perspective it is possible to discern a general trend in the law. Both in statute and caselaw there has been a movement away from allowing

${ }^{22}$ The Disablement Income Group opposed improvements to the tort system proposed in the 1970's because they would make “an elite group even more elite.” The Times, July 251978.

${ }^{23}$ Similarly John Fleming, in "Collateral Benefits" in the International Encyclopaedia of Comparative Law (Vol. XI) (1986) chap 11 - 3 suggests: “One perfectly legitimate reason for this diversity is that the varying nature of the differing benefits may simply not warrant the same solution. Here, as elsewhere, simple answers might be the mark of simple minds." 
cumulation of collateral benefits and, instead, a principle of preventing multiple recoveries has been adopted. ${ }^{24}$

This trend is especially seen in relation to state benefits. Although the early twentieth century saw an increase in both public and private sources of support for accident victims, there was almost no discussion ${ }^{25}$ of the potential overlap of compensation until Beveridge reported in $1942 .{ }^{26}$ The concern then was about the extent that the tort system for work injuries should continue to operate alongside a revised and extended post-war welfare state which included a no-fault industrial injury scheme, nationalised by the Attlee Government in 1946. Following another report which reflected major divisions on this issue,${ }^{27}$ the Law Reform (Personal Injuries) Act 1948 was passed. The tort system was allowed to continue but the Act required certain social security benefits to be offset from damages. However, this measure reflected a compromise between the divided parties because the benefits were to be offset by only half of their value and only for five years after the injury.

\footnotetext{
${ }^{24}$ Lord Bridge in Hussain v New Taplow Paper Mills Ltd [1988] AC 514 at 527 summarised the modern approach as involving “... the rule that prima facie the only recoverable loss is the net loss. Financial gains accruing to the plaintiff which he would not have received but for the event which constitutes the plaintiff's cause of action are prima facie to be taken into account in mitigation of losses which that event occasions to him."
}

${ }^{25}$ However, the problem of overlap in relation to other than state benefits did receive legislative attention in the Workmen's Compensation Acts 1925 - 45. There was concern that an employer should not be liable to pay both damages in tort and the no-fault compensation made available under the Acts. It was therefore provided that an injured person had to choose either to accept the no-fault benefit or to sue for damages at common law; he could not succeed in both. See in this book the chapter by Jenny Steele. Although this "election rule" was intended to prevent the possibility of double compensation, in practice it led to the exclusion of the vast majority of injured workers from the tort system. See P. W. J. Bartrip, Workmen's Compensation in Twentieth Century Britain (Avebury: Gower Publishing, 1987) chapter 10 .

${ }^{26}$ Social Insurance and Allied Services, Report by Sir William Beveridge, (1942) cmd 6404.

${ }^{27}$ Report of the Departmental Committee on Alternative Remedies chaired by Sir William Monckton (1946) cmd 6860. 
There was greater readiness to accept this compromise measure because in the immediate post-war years the overlapping systems were thought to be much less of a problem than they later became. No one expected either that personal injury litigation would increase as rapidly as it did, or that the range and value of social security benefits would change so quickly. The introduction of each new benefit resulted in litigation about whether or not it was to be deducted from damages. Up to the 1970's the judiciary vacillated between the different solutions, sometimes applying the collateral source rule to prevent deduction, sometimes not. However, in the 1970's and 80's there was increasing recognition of the wastefulness of what was perceived as double compensation with the result that more and more cases favoured deduction. This trend was confirmed by the House of Lords in Hodgson v Trapp ${ }^{28}$ and Hussain v New Taplow Paper Mills. ${ }^{29}$ As a result the Law Commission in 1997 noted that there had been a "clear shift of approach against double recovery." 30

It is in the context of this shift in judicial policy that in 1989 legislation was introduced to require certain social security benefits to be deducted from damages and to be reimbursed to the state. The legislation met with considerable opposition. However, the Government was anxious to reduce public expenditure and keen to end what it saw as either a subsidy to insurers or over-compensation of claimants. Beginning in the 1980 's, therefore, via a combination of statute and caselaw there was a clear move towards preventing injured people from recovering twice if they received social security benefits in addition to damages. The judicial move to reduction was followed by the statutory move to recoupment and benefit recovery. It is to the political influences upon that last development that we now turn.

\section{BENEFIT RECOVERY: POLITICS AND TORT REFORM}

\footnotetext{
${ }^{28}$ [1989] AC 807.

${ }^{29}[1988]$ AC 514.

${ }^{30}$ Law Commission Consultation Paper No 147 (1997) Collateral Benefits para 2.103.
} 
Following the changes made in 1948, there were no further reports on the potential effect of state benefits on damages until the 1970's. The Law Commission in 1973 recommended that, with the exception of those benefits prescribed by the 1948 Act, social security benefits should be left out of account. ${ }^{31}$ By contrast and only five years later, the Pearson Commission recommended that all benefits should be fully offset from their corresponding part of the damages award. ${ }^{32}$ This would have reduced damages overall by about twenty per cent. However, the Commission did not recommend a recovery of benefit scheme. It rejected the idea of giving the state a right of subrogation to reclaim benefits from tortfeasors because of the practical difficulties involved and because it thought that it would increase administration and litigation costs.

The Pearson Commission's view that the duplication of social security and tort payments should be brought to an end was accepted in principle by the Government in a White Paper in $1981 .^{33}$ But before endorsing the Commission's proposal that benefits should be fully offset against damages, the Government wished to consider again whether it might also be possible for the state to recover those benefits. A recovery scheme would have the advantage, when compared to offsetting, of not reducing the liability of negligent defendants. In addition, for work injuries it was thought that the sums recovered might finance improved state provision for all injured workers whether or not they could claim in tort. Against this there continued to be concern that the state's intervention in tort claims would require an increase in staff numbers out of proportion to the benefit recovered. In addition it was thought difficult to set up an effective system to deal with cases settled out of court - the way in which almost all cases are determined in practice. Because of these fears the Government concluded that, on balance, recovery was still impractical. It therefore proposed to

\footnotetext{
${ }^{31}$ Law Commission Report No 56 (1973) Report on Personal Injury Litigation - Assessment of Damages.

${ }^{32}$ Op cit above note 7 at vol 1 chap 13 especially para 541.

${ }^{33}$ Reform of the Industrial Injuries Scheme (1981, cmnd 8402).
} 
adopt the Pearson proposals for the offsetting of benefit, and to abandon the idea of state recoupment.

However, further public comment was invited and this produced some responses suggesting that the recovery option should not be abandoned without more investigation. In particular the Industrial Injuries Advisory Council stated that it was not convinced that the cost of operating a recovery scheme was prohibitive. Amendments tabled to the Administration of Justice Bill 1982 were designed to allow benefits to be recovered. Although these were subsequently withdrawn because of drafting difficulties, the Government indicated that it was sympathetic to their aims and that it intended to introduce legislation when a workable scheme could be agreed. By this time the political climate had also changed. The corporate welfarist philosophy of previous Labour Governments had given way to the monetary economics of Thatcherite Conservatism to which state subsidies to employers and duplicated help for welfare recipients were anathema. The possibility of ending these subsidies - or at least recovering the public expenditure involved - was bound to receive enthusiastic political support.

In spite of the increasingly favourable political climate the promised legislation did not materialise. As a result in 1986 the National Audit Office criticised the Department of Health and Social Security for its failure to investigate the feasibility of a cost-effective recovery scheme. ${ }^{34}$ It called for detailed research and for the necessary calculations to be made. This led to the setting up of an inter-departmental review but, typical of the Thatcher years, civil servants were not trusted with effecting fundamental reform. Instead the management consultants, Touche Ross, were commissioned to report on the practicalities involved. The accountancy firm encountered strong opposition to recovery from all they interviewed. ${ }^{35}$ The objections were based on the grounds both of principle and practical implementation. Despite

\footnotetext{
${ }^{34}$ Report by the Comptroller and Auditor General, Recovery of Social Security Benefits when Damages in Tort are Awarded (1985 - 86, HC 553). As a result the Public Accounts Committee called for more vigorous action in its Fourth Report, Compensation Recovery 1987 - 88 (HC 120).

35 Touche Ross, Recovery of Benefits in Tort Damages Awards (1988) para 2.2.
} 
this, and somewhat unsurprisingly, the commissioned report found that such a scheme was feasible. $^{36}$

When the proposals for reform became known these too met with widespread criticism. It is difficult to exaggerate the extent of this opposition. Only the National Audit Office and the Public Accounts Committee supported the proposals. Strong opposition came from the Law Society, the Association of British Insurers, and even certain judges who made public their view that the changes might make settlements harder to achieve. ${ }^{37}$ Both sides of industry - the Confederation of British Industry and the Trades Union Congress - expressed their concern about the proposed scheme. The Industrial Injuries Advisory Council had previously been in favour of the Pearson Commission's proposal for offsetting benefits from damages. However, it was very critical of the new suggestions and was dismayed to note that any savings to be made were not to be earmarked for improvement to the industrial scheme. ${ }^{38}$ An editorial in Legal Action simply described the proposals as "fiscal opportunism riding on the back of inadequate analysis." ${ }^{39}$ However, such criticism made little difference to a Government who, at that time, were prepared to introduce legislation in the teeth of opposition from establishment groups. The Government therefore went ahead with its management consultant's proposals to make defendants fully responsible for the injuries they cause, and thus ensure that there was no possibility of overcompensation. The fact that these goals could be achieved whilst reducing public expenditure proved far too tempting. Following the series of privatisations of state-run and subsidised industries, it was now time for tort defendants to pay their own way.

It was thus very much as a result of the prevailing political philosophy that the recovery scheme was first set up by the Social Security Act 1989. It was only a year

\footnotetext{
${ }^{36}$ Ibid.

${ }^{37}$ For example, Lord Griffiths, HL Deb vol 509 col 934 (June 29, 1988).

${ }^{38}$ IIAC, Recovery of Social Security Benefits when Damages in Tort are Awarded (1988) and Position Paper (No 3) (1988).
}

${ }^{39}$ Legal Action, (May, 1988) 3. 
later that Margaret Thatcher left office. Her departure made no difference to the scheme. In fact it soon became widely accepted. The practical difficulties that were feared did not materialise. Litigation was not impeded, settlements were not delayed, and there were only limited additional administrative costs. Although there had been a very poor track record of computerisation of information in the public sector, the new national database of social security payments worked surprising well. CRU also proved very efficient in producing the relevant certificates on time and communicating with the litigating parties. ${ }^{40}$ Practitioners became used to the new procedure and compliance rates were high. As acknowledged by the Association of British Insurers in 1995, the anticipated "bureaucratic nightmare" did not materialise. ${ }^{41}$ Money began to flow into the public purse.

Following its successful implementation, the scheme was revised by the Conservative Government seven years later. The Social Security (Recovery of Benefits) Act 1997 was almost the last legislative effort of the departing Government led by John Major. It expanded the scheme by removing the exemption from recovery for cases where the damages were $£ 2,500$ or less. This exemption had meant that in about half of all cases recovery of benefits was avoided because practitioners on both sides were very aware of the importance of crystallising the value of small claims at or below the threshold figure. ${ }^{42}$ Benefit planning became an important consideration in the settlement of small claims. By removing the exemption many more claims fell into the net, settlement figures became more varied, and more benefit was recovered for the public purse.

${ }^{40}$ Department for Work and Pensions, Customer Satisfaction Survey (2006) www.dwp.gov.uk/otherspecialists/compensation-recovery-unit/performance-and-statistics/customer-satisfaction-survey

${ }^{41}$ Minutes of Evidence given by the ABI, Fourth Report of the Social Security Select Committee (1995) HC 198, at 77.

${ }^{42}$ Department of Social Security, Memorandum of Evidence to the Social Security Select Committee (1995) HC 196, para 40. 
The new Labour Government which took office in 1997 was initially determined to maintain the fiscal prudence of the previous administration. This meant that not only was there continued support for the recovery scheme but also a plan was immediately drawn up to extend it. The Law Commission had previously issued a Consultation Paper in which it had suggested that hospital treatment costs might be included in the recovery scheme. ${ }^{43}$ Without waiting for the Law Commission to make its final report, the new Labour Government quickly announced its intention to go down this route. In Gordon Brown's very first budget as Chancellor of the Exchequer in July 1997 he stated that he intended to recover from insurers the full cost of treatment. However, this was to be done only for the existing class of cases for which some limited payment was already required, that is, for those involving road accidents. Eighteen months later a Bill was introduced to Parliament and the Road Traffic (NHS Charges) Act came into force in April 1999. In 2007 the scheme was again extended so as to cover all types of personal injury no matter what their cause when Part III of the Health and Social Care (Community Health and Standards) Act 2003 was brought into force. By then the recovery scheme was well established and not subject to any of the challenges that had been voiced before its introduction almost twenty years previously. It was, and remains, well off the political radar.

\section{JUSTIFICATIONS FOR BENEFIT RECOVERY RE-EXAMINED}

In spite of the present lack of criticism of the scheme, the reasons that were given for its establishment merit re-examination. Some major reservations about the scheme are outlined below as a precursor for suggesting that there are alternative methods of raising money for the public purse. This leads into the next section which contrasts the emphasis upon individual wrongdoing in the present scheme in allocating costs to precise risk bearers with an alternative approach to compensation which emphasises a wider community responsibility for injury.

\footnotetext{
${ }^{43}$ Law Commission Consultation Paper No 144 (1996) Medical, Nursing and other Expenses para 3.19 et seq. C. Leech, "Recoupment of NHS Medical Treatment Costs after Compensation Claims" (1997) 147 New L J 663.
} 


\section{(1) Preventing overcompensation?}

A major justification put forward for the present scheme is that it prevents excessive and wasteful overcompensation. However, in practice, it is uncommon for duplicate payments to result in this. According to the Trades Union Congress the receipt of benefits in addition to damages in many cases does not lead to too much money being paid:

"There is nothing inherently wrong in receiving compensation from two or more sources. There might only be cause for concern if people were being compensated excessively.... However, the existing evidence firmly suggests ... the problem is not one of overcompensation but of under-compensation., 44

There are many reasons why the damages may prove insufficient to meet the claimant's loss but two examples will here suffice. Firstly, damages may deliberately be reduced and not be intended to compensate in full. An illustration of this is where the defence of contributory negligence is proven or alleged: damages are reduced and may then be insufficient to meet the claimant's future needs. It has been estimated that this defence reduces damages in about a quarter of all settlements. ${ }^{45}$ Also in the settlement process the offer of compensation will inevitably be less than the full damages which a court would award. This is because allowance is made not only for avoiding the risks and the trauma associated with proceeding to trial, but also for the fact that the compensation is received sooner than would otherwise be the case. A lesser sum is then accepted than the actual loss suffered.

A second reason for under-compensation lies in the way in which the courts assess damages, especially where future losses are being quantified. The approach differs markedly from that of an economist and it has been criticised by one expert in labour

${ }^{44}$ Trades Union Congress, Full Recovery of State Benefits from Tort Damages Awards: Memorandum of Comments (September 1988) paras 9 - 11.

${ }^{45}$ D. Harris et al, Compensation and Support for Illness and Injury (Oxford: OUP, 1984) 91. 
market analysis in particular. ${ }^{46}$ In essence, courts take too little notice of the effects of disability upon future employment prospects. In addition, they insufficiently account for inflation. It is only in recent years that basic actuarial principles have been employed to assess loss with more accuracy. Nevertheless excessive reductions from what ought to be awarded continue to be made. The most notable example at present concerns the discount rate which must be used by courts to allow for the accelerated receipt of a lump sum of damages in substitution of a continuing future loss. The reduction in damages has been shown to be far too high for very many years ${ }^{47}$ and the discount rate has never matched the true rate of return. ${ }^{48}$ The result is that in serious injury cases too little is paid to meet the losses that are expected to accrue in the future. Under-compensation of the long-term injured is the norm; waste caused by duplication of payment is rare.

\section{(2) Punishing and deterring wrongdoers?}

One objective of the recovery scheme is to ensure that the defendant gets his just deserts by preventing the transfer of the some of the responsibility for payment to the state. However, in practice this also needs severe qualification because most individual responsibility for wrongdoing has been removed from the tort system. People who have caused personal injury and committed a tort are almost never required to pay damages personally.

${ }^{46}$ R. Lewis, R. McNabb and V. Wass, "Court Awards of Damages for Loss of Future Earnings: An Empirical Study and an Alternative Method of Calculation” (2002) 29 J of Law \& Society 406 and [2002] J of Personal Injury Law 151 and, by the same authors, "Loss of Earnings Following Personal Injury: Do the Courts Adequately Compensate Injured Parties?” (2003) 113 Economic Journal 568.

${ }^{47}$ See the comments of the former Government Chief Actuary, Chris Daykin, "Fair Compensation Needs Actuaries" [2009] J Personal Injury Law 48 - 65. R. Cropper and I. Gunn, "The Discount Rate: If I was going there I would not start from here” [2011] J Personal Injury Law 78.

${ }^{48}$ Introduction to the Government Actuary's Department, Actuarial Tables for Use in Personal Injury and Fatal Accident Cases (London: The Stationery Office, $5^{\text {th }}$ ed 2004) para 15. 
There are many reasons for doubting whether tort law can act effectively as a deterrent and prevent undue risks being taken. ${ }^{49}$ Here we focus upon who actually pays damages. Fear of civil liability plays little or no part in regulating risk taking behaviour because of the protection afforded by liability insurance. In nine out of ten cases the real defendants are insurance companies, with the remainder comprising large self-insured organisations or public bodies. ${ }^{50}$ People take care to avoid causing injury not because of fear of civil liability but because they wish to reduce the risk of injuring themselves, their property or other people. Self preservation and a natural concern for the safety of others are the important motivating factors. Finally, it is clear that the possibility of being found guilty of a crime is far more effective as a specific deterrent than the imposition of civil liability; the tort sanction plays little or no part.

As a result of such attacks upon the deterrent effect of tort law the Law Commission concluded that

"... as tort law in general has difficulty in deterring wrongdoing, the deterrent effect of damages being increased by the amount of the collateral benefits must surely be negligible. Accordingly we do not think that an approach to collateral benefits which diverges from that which the compensation aim dictates can be justified on the basis of the deterrence it achieves."

\section{(3) Reinforcing the basic justice and efficiency of the tort system?}

Although the recovery scheme reinforces the tort system there are many features of that system which can be called into question. Any apparent justice of the scheme in theory is severely undermined by the position experienced by litigators in practice. Most notably the emphasis upon fault and cause as providing a sufficient moral basis

\footnotetext{
${ }^{49}$ See further P. Cane, Atiyah's Accidents, Compensation and the Law (Cambridge: CUP, $7^{\text {th }}$ ed
} 2006) 424 - 439. The arguments based on the wider economic perspective of market deterrence are summarised at $459-458$.

${ }^{50}$ The Pearson Commission op cit above note 7 vol 2 para 509 estimated that insurers dealt with 88 per cent of tort claims and paid 94 per cent of the total damages.

${ }^{51}$ Law Commission Consultation Paper Collateral Benefits (1997) para 4.17. 
for the imposition of liability has been seen as severely misplaced. ${ }^{52}$ The rule is too uncertain to apply to the individual facts of particular accidents. For reasons of cost and administrative efficiency, insurers have been forced to substitute other criteria for fault. Mechanical rules of thumb - such as the car running into the back of another always being found the one at fault - replace any detailed investigation into blame. There is neither the time nor resources to instruct experts to analyse the scene of each road accident and precisely measure its effect upon the individual claimant. Cases are disposed of on the basis of paperwork alone, and this may bear only a limited relationship to what actually occurred. If a case gets to court it has been argued that the finding of fact is so uncertain that you might as well toss a coin to determine the result. $^{53}$

Apart from difficulties in assembling and presenting evidence of wrongdoing, there is also concern about how judges interpret it for they are naturally inclined to make some provision for the tragic victims of accidents coming before them. Legal practitioners are only too aware that liability is sometimes imposed out of natural sympathy for the victim rather than because of the wrongdoing of the defendant. The overall result is that severe doubt can be cast upon the basic justice of the personal injury system.

The efficiency of the tort process is no less subject to criticism, and yet that process forms the foundation upon which the benefit recovery scheme has been constructed. The cost of operating the tort system amounts to 85 per cent of the value of tort payments distributed to claimants. ${ }^{54}$ Put another way, for every pound spent upon the

${ }^{52} \mathrm{P}$. Cane op cit above note 49 chapter 7.

${ }^{53}$ D. W. Elliott and H. Street, Road Accidents (London: Penguin, 1968) 243.

${ }^{54}$ The Pearson Report op cit above note 7 at vol 1 para 256. The Lord Chancellor's Report of the Review Body on Civil Justice in 1986 estimated that the cost of the tort system consumed 50 to 70 per cent of the total compensation awarded in personal injury cases. Lord Justice Jackson found similarly very high costs in his Review of Civil Litigation Costs: Final Report (January 2010). Data collected for one survey showed that for 280 cases which had come before the District Court the claimant costs alone 
system in total, 55 pence goes to the claimant and 45 pence in costs. These costs include not only the legal costs of both sides which insurers have to meet but also the insurers' costs in administering the system. Claimants' legal costs alone are about 30 per cent of the damages awarded. ${ }^{55}$ Criticism can also be made of the time it takes to achieve settlement. Even though small sums are usually involved, the majority of claims take between one and two years to process. ${ }^{56}$ If a case goes to court the time taken is much longer, averaging between three and five years. ${ }^{57}$ Overall it is difficult to conclude that the tort system is an efficient means of processing compensation or that it provides a suitable foundation for raising public funds.

\section{(4) Raising significant sums for the public purse?}

Since it began in 1990 the recovery scheme has clawed back increasing amounts of benefit, especially since health service charges were added in 1999. By the new millennium the social security benefits recovered had risen steadily and reached $£ 201$ million a year. Since then, caused partly by a marked decline in work accidents, the amounts recovered have fallen by a third so that in $2010-11$ only $£ 140$ million was recouped. To this must be added the health service charges recovered for that year of $£ 195$ million so that in total $£ 335$ million was repaid to the public purse. $^{58}$

amounted to $£ 1-80$ p for every $£ 1$ of damages paid. On average costs exceeded damages for cases settled up to $£ 15,000$ in the "fast track" procedure.

\footnotetext{
${ }^{55}$ London International Insurance and Reinsurance Market Association, Fourth UK Bodily Injury Awards Study (2007) para 7.21.

${ }^{56}$ The Department of Social Security reported an average settlement period of 2.3 years for those tort cases where benefits were recovered from 1990 - 94, although in 28 per cent of cases the recoupment period lasted for between three and five years. See the DSS Memorandum of Evidence to the Social
} Security Select Committee (1995) HC 196 appendix B. Similarly, P. Pleasence, Personal Injury Litigation in Practice (1998) p 65 fig 4.21. The Pearson Report op cit vol 2 table 17 found that 49 per cent of claims settled within a year and 80 per cent within two years of injury.

\footnotetext{
57 The Pearson Report op cit above note 7 at vol 2 table 129, and similarly the Lord Chancellor's Department, Report of the Review Body on Civil Justice (1988) Cmd 394.

${ }^{58}$ Above notes 8 and 11 .
} 
However, the steady increase in the total benefits recovered does not mean that the scheme is of great importance to the Exchequer. Within the larger picture of Government expenditure the savings are very small indeed. In 2009 - 10 benefit expenditure alone was $£ 147$ billion $^{59}$ with health expenditure a further $£ 122$ billion. This means that the benefits recovered amounted to less than 0.1 per cent of the total expenditure on health and welfare alone. Although the scheme may have been an attractive political stick with which to beat insurers and make tortfeasors appear to pay their "just desserts," its overall effect upon the public purse is limited.

\section{Taxation as an alternative method of raising revenue}

There are many other means of replenishing public funds which are more efficient than this "tax on accidents." ${ }^{60}$ Direct taxation of income is but one. Increasing the existing tax upon insurance premiums is another. In other countries providers of collateral benefits are given extensive subrogation rights to recover from the tortfeasor the benefits paid to the claimant. However, they enforce these rights through standard recovery agreements under which liability insurers agree in advance to repay a percentage of the compensation bill. This avoids litigating individual cases and makes subrogation administratively workable and financially acceptable. ${ }^{61}$

The objection to these alternative methods of raising revenue is that they break or at least dilute the link between those who cause accidents and those who pay for them. This connection is the key feature of tort for those who argue that the system can be an effective deterrent of those who would otherwise take unwarranted risks. The connection also enables tort to reflect moral precepts in a way which other payment systems are unable to emulate because they do not seek to establish responsibility for

\footnotetext{
${ }^{59}$ Department for Work and Pensions, Benefit Expenditure Tables, http://statistics.dwp.gov.uk/asd/asd4/index.php?page=medium term

${ }^{60}$ Anne Widdecombe, HC Deb vol 322 col 166 (December 8, 1998).

${ }^{61}$ See W. Pfenningstorf and D. Gifford, A Comparative Study of Liability Law and Compensation in Ten Countries and the USA (1991) 134, and U. Magnus op cit above note 3.
} 
injury in the same way; they do not require the attribution of fault or cause in such detail.

Against this many believe that the moral force of tort and its effectiveness as a deterrent is fatally impaired in practice. A major reason for this is the existence of liability insurance which removes the costs of the accident from the individual who may have caused it and spreads it among a wide group of premium payers. This group constitutes a large section of the population as a whole and inevitably, one way or another, the costs are widely distributed throughout society. The factors affecting the cost of the premiums paid by those insured very often bear little relationship to the risk of individual members causing personal injury. ${ }^{62}$ Furthermore, the connection between those who cause injury and those who pay for it is so weak that it makes little difference whether premium payers fund the compensation or whether it comes from taxpayers in general. The two groups substantially overlap, and much of the deterrent and moral force of tort liability is thus lost.

This argument forms the foundation for a fundamental criticism of the benefit recovery scheme. If indeed it makes little difference whether compensation is paid by insurance premium payers or by taxpayers and that, in effect, we all fund both the welfare state and tort then recovering benefits merely takes money with one hand only to give it back with the other. That is, money is recovered from premium payers only to be transferred to taxpayers even though these are substantially the same groups. Rather than embarking upon the individual assessment of loss and exact calculation of benefit received it is more efficient to raise money by other means.

This argument was rejected by the Law Commission. It suggested that recovery of benefit "confines the cost of tort compensation to those who benefit from activities

\footnotetext{
${ }^{62}$ See for example how employer's liability rates are calculated. P. Atiyah, “Accident prevention and variable premium rates for work-related accidents" (1975) 4 Industrial LJ 1. Similar concerns exist for motor insurance as discussed in Chris Parsons, An Analysis of Current Problems in the UK Liability Insurance Market, Office of Fair Trading Report (London: OFT659a, 2003).
} 
leading to tort liability." ${ }^{63}$ However, the costs created by motoring accidents, for example, are clearly not confined to motorists alone but are substantially distributed to the community at large. This leads us to consider, in the next section, an alternative approach to compensation not based upon the individualised assessment of fault and responsibility embodied in tort and less concerned about allocating costs to precise risk groups.

\section{CONTRASTING COMMUNITY RESPONSIBILITY FOR INJURY}

The recovery of benefits legislation seems a world away from the trend in favour of community responsibility and community payment for injury identified in a famous article by John Fleming in $1966 .{ }^{64}$ Fleming noted that at that time Britain was in the vanguard in rejecting the economic calculus requiring particular activities to bear their full costs. He thought this "insensitivity for finer discriminations between different 'risk communities' " was least objectionable in the case of road accidents because transport is an activity from which we all benefit. In his view it made little difference whether the bill was paid by general taxation or by the insurance premium paying community. This sharply contrasts with the Law Commission views noted immediately above.

Fleming thought that wider acceptance of community responsibility for injury would eventually lead to a review of the future of tort liability. ${ }^{65}$ This indeed happened in New Zealand where "community responsibility" was one of the five guiding principles of the Woodhouse Report which heralded the far reaching changes set in place in that country. ${ }^{66}$ The Accident Compensation Act 1972 created a uniform

\footnotetext{
${ }^{63}$ Consultation Paper No 144 (1996) para 3.25 and Law Commission Report No 262 Damages for Personal Injury: Collateral Benefits (1999) para 3.27.

64 “The Collateral Source Rule and Loss Allocation in Tort” (1966) 54 Cal L Rev 1478.

${ }^{65}$ H. Luntz, op cit above note 21 at 406.

${ }^{66}$ Royal Commission of Inquiry, Report on Compensation for Personal Injury in New Zealand (1967). For similar alternative visions see S. Sugarman, "Personal Injury and Social Policy Institutional and Ideological Alternatives" in N. Mullany and A. M. Linden (eds), Torts Tomorrow
} 
compensation scheme in substitution for almost all actions in tort for personal injury. The substantial removal of the tort system caught many potential opposition groups by surprise. The result has been described as causing the first casualty among the core common law systems of the world. Despite criticism, much of it misinformed, the scheme continues to operate successfully. The universal coverage it provides on a nofault basis has recently been compared with tort and has been said to result in more injured people receiving compensation; a higher proportion of the total cost going into providing benefits for claimants; benefits being paid more quickly; and better claimant outcomes, especially for returning to work and improved health. ${ }^{67}$ New Zealanders have no desire to return to the old system.

Fleming's forecast that such fundamental reform would spread to other common law countries has proved not to be the case. ${ }^{68}$ In fact in Britain the tort system, far from being abolished or falling into decline, has been made more important. Dominated by an exponential increase in road traffic claims, the number and type of claims and the level of damages now available far exceed what might have been projected by even the most ardent tort supporter who opposed Fleming's views over forty years ago. ${ }^{69}$ It is somewhat ironic that it is in other parts of the common law world, and not in Britain, that significant restrictions have been placed on its use. Tort flourishes here and Britain is no longer in Fleming's vanguard.

\section{CONCLUSION}

(Sydney: LBC Information Services, 1998) and S. Sugarman, Doing Away with Personal Injury Law (New York: Quorum, 1989) and T. Ison, Compensation Systems for Injury and Disease: The Policy Choices (Toronto: Butterworths, 1994).

${ }^{67}$ Pricewaterhouse Coopers, Accident Compensation in New Zealand: Scheme Review (March 2008), Executive Summary, section3.

${ }^{68}$ J. G. Fleming, "Is there a future for tort?” (1984) 58 Australian LJ 131 at 142.

${ }^{69}$ Trends are analysed in R. Lewis, K. Oliphant and A. Morris, "Tort Personal Injury Claim Statistics: Is there a Compensation Culture in the United Kingdom?” (2006) 14 Torts LJ 158. 
The benefit recovery system departs from notions of community responsibility for injury and entrenches a discredited tort liability system as a means of raising public revenue. The recoupment principle reasserts the primacy of the tort obligation with its attendant support for individualism and its rhetoric of punishing wrongdoers - no matter how difficult it may be to identify them with any accuracy or make them pay in practice. Irrespective of how expensive, irrational, or even grossly unfair the fault principle appears in practice each pound of cost is to be counted and allocated its "proper" place. It is insurers - or rather their policyholders and, indirectly, the community at large - who must pay. Although the resulting "stealth tax" is a convenient political method of raising public revenue, the recoupment principle, as applied to social security benefits and health costs, further reinforces the tort system. The wastefulness and inequities of the basic principle upon which that system is founded - the fault principle - are lost in the narrower focus and in the political expediencies of the moment.

Of course, there are alternative methods of funding compensation schemes and obtaining money from insurers or those considered to be risk groups. Paths that might have been explored include taxing insurance premiums or collecting a European-style levy from insurers under standard loss-sharing agreements. New Zealand chose to increase the price of petrol and the road fund licence, as well as imposing a levy on employers' wage bills. But that country also funded its new scheme by direct taxation. The bill for the compensation, rehabilitation and medical treatment of the injured was therefore met by raising revenue from a wide base. The cost was not focused unduly upon particular groups or affected by whether fault could be proved.

Did the legislation which is the subject of this chapter merely provide sensible measures to account for the existing welfare system, or did it legislate so as to further impede any more radical reform of tort law and against wider societal responsibility for injury and disablement? The argument here is that the latter is the correct analysis, and the recovery of benefit legislation was against and not for the welfare state. What of tort? Far from "withering away," as some had forecast forty years ago, tort is flourishing. Whether it should do so is a matter of concern to all those who favour wider community responsibility for accident and disease. What is not in doubt is that 
statutes should be a key focus of study for the tort scholar concerned about reflecting the role that law actually plays in society. 